\title{
ПЕРЕКЛАДОЗНАВСТВО
}

UDC 811.111'27:811.161.2'27

DOI https://doi.org/10.32838/2663-6069/2020.2-3/10

Ahieieva $V_{\text {. O. }}$.

Petro Mohyla Black Sea National University

\section{COMIC AS LINGUISTIC CATEGORY: CLASSIFICATION, PARAMETRES AND TRANSLATION}

The article analyzes the concept of comic as linguistic category. The article focuses attention on such aspects of the category of comic as classification, parameters of comic and the difficulties of translation of comic.

It is singled out that the notion of concept comic goes beyond the linguistic aspect. That is why this language phenomenon is also studied from the point of view of socio-cultural aspect and the norms of human behavior in society. The category of comic is complex and ambiguous. In general, within this notion we understand the influence of jokes, for example, causing laughter. There are several methods that help to achieve laughter. Among them we distinguish irony, sarcasm, pun, allusion, periphrases, oxymoron, metaphor etc. Because of the multiaspect character of comic, this term is often used simultaneously with its similar synonymous humor, laughter, comic, funny, meaningless, cute, witty, joke, absurdity, irony, sarcasm, satire, etc. As for the categories of comic, scholars single out: analysis of style of a certain comic text, allocation and description of special features of comic text style of the specific authors; defining and studying the language and methods of realization of the category of comic on the example of a particular language; characteristics of the language parameters of specific subspecies of the category of comic.

The category of comic is also subdivided into three groups. The first group is represented by understandable and easily recognizable humor based on the comic situation. The second type is presented by jokes based on the cultural base of the source language. And to the third type we refer linguistic humor. This type of humor in its structure is the most difficult to decode into a different language, because it is based on a game of words (pun), which, unfortunately, is usually considered to be not subject to translation. And, as for the translation aspect, it is necessary for translators to find a situational equivalent, an equivalent with an increased level of emotionality; to use transcoding or the combination of transcription and transliteration with the addition of word-forming morpheme; and to apply lexical and semantic and phonetically-imitating transformations.

Key words: linguistic category, comic, translation, classification of comic, parameters of comic.

Formulation of a research problem. In the context of linguistic analysis of satirical text, there is a true need for fundamental and comprehensive study of comic methods. The comic category has long existed in the minds of people; it manifests itself in both oral and written communication, as well as it is recorded in many studies. The main idea and prerequisite of the comic is the discrepancy of objective properties of the subject or the phenomenon of the norm available in the perceived consciousness. There are numerous attempts by scientists to investigate individual aspects of the comic.

All these problems only outline the complexity of the study of this phenomenon. The study of the comic as a linguistic category comes to the fore.
The tools and techniques of the comic are usually examined through the prism of unique author's idiol. However, an integrated description of such a complex and ambiguous category as comic cannot be achieved only by means of linguistic expression.

Thus, the researchers of comic try to explain the culture conditioned behavior of the individual as a representative of the socio-cultural community, which brings to the second plan the question of studying the culture of the people, knowledge of values, existing norms and roles of social behavior. Only in certain cases the translation of jokes manages to convey the comic corresponding units in the translation language, which together could produce the same pragmatic effect. 
Analysis of the latest research into this problem proved that the phenomenon of comic in speech is complex and ambiguous. Its study focuses on types of humor that is transmitted directly through the language, but not on non-verbal forms, such as a hoax or a farce. The linguistic researches of comic at the present stage are concerned about the questions of theoretical instruments (I. A. Antonio, A. V. Karasyk, O. D. Koshelev, M. O. Kulinight, G. H. Kyanimov); peculiarities of the construction and perception of comic text (S. Tardo, T. A. Vasylchenko, S. Konshyna, I. E. Snikhovska); forms, stylistic means and devices (A. G. Boldyrev, O. M. Kalyta, S. Kapkova, J. Koloninese, A. K. Kutoyan, A. S. Leskiv, O. B. Shon); cognitive basis of creation of comic and language game (M. A. Yevstafyeva, I. Kosolbov, A. E. Levytsky, I. E. Snikhovska); of humorous discourse (M. V. Mironenko, A. O. Proskurina, O. V. Kharchenko).

Setting objectives. The main task of the article is to analyze the language phenomenon of comic as a linguistic category, that is, to compare the approaches to the definition of the category of comic, to define its parameters (how comic is shown in the language) and to study the peculiarities of its translation.

Statement regarding the basic material of the research. Comic as a component of non-verbal communication and perception of the world has always had great significance, as well as linguistic and informative value. Under the comic effect, we understand the impact and pragmatics of jokes, based on inconsistencies in the values, for example, literal and contextual, causing laughter. Traditionally, the means of creating a comic effect is taken to include stylistic techniques such as irony, sarcasm, pun, allusion, periphrases, oxymoron, metaphor etc. As a rule, the comic effect gives birth to such a deviation, which provides additional meaning, the second plan, sharply contrasts with the first. Laughter is caused by the diversity of realistically perceived information with an objective prognosis of this information, that is, there is a violation of cognitive rules. Laughter is considered an indispensable result of both humorous and satirical creation, but the essence and the purpose of laughter differ. Various forms and linguistic genres of comic are distinguished mainly for the dominant purpose.

One of the common ways to implement the comic is to create linguistic works that represent in their turn the result of discursive activity of the linguistic personality. At the same time, they allow to judge the individual peculiarities of the communicative competence of their creator, about latent processes of linguistic consciousness. There was a tradition, within which the word discourse refers to a coherent linguistic work in the variety of its cognitive-communication functions. Deviations from the norms give the greatest possibility to create more or less complete and satisfactory comic theory.

Difficulties in the category of comic, according to A. V. Utkina, lie in the multiaspect character of the analyzed category [8, p. 37], the result of which can be considered as a significant number of adjacent and similar terms understood more often synonymous: humor, laughter, comic, funny, meaningless, cute, witty, joke, absurdity, irony, sarcasm, satire, etc.

In general, the category of comic performs the following functions: 1) the aesthetic function (joke for the sake of the game);2) the socialization function (the ability to express funny, which is determined by cultural peculiarities); 3) the communicative function (normalization of interpersonal communication); 4) the catharsimetric function (laugh at yourself); 5) the self-regulation function (ability to look at the problem from aside, from different angles); 6) the heuristic function (a mismatch between the notion of a subject and its actual content); 7) the creative function (the connection of the previously unrelated facts to achieve a higher level of thought).

Thus, in linguistics it is traditionally to allocate such directions of the category of comic as: analysis of style of a certain comic text, allocation and description of special features of comic text style of the specific authors; defining and studying the language and methods of realization of the category of comic on the example of a particular language; characteristics of the language parameters of specific subspecies of the category of comic (irony, satire, sarcasm, humor).

Representatives of various scientific schools of traditions allocate from two (humor and satire) up to seven (humor, satire, joke, ridicule, irony, grotesque, sarcasm) the basic forms of comic, while in some concepts the humor and satire are regarded as two equal basic forms of comic, and the rest (irony, grotesque, etc.) have the status of expressive means of comic, which are used by humor and satire. In linguistics humor is divided into three main groups: universal; based on the component of the original culture (culture-based); and linguistic.

The first group, conventionally named "universal humor", is characterized as such that causes the slightest difficulties in the translation work. This type of humor is usually understandable and easily recognizable, regardless of belonging to a particular cultural environment/linguistic group, because it is 
based on common human, universal realities and is usually based on the comic situation. Jokes about men and wives, witty children's statements, jokes about the work and the guide, etc. can serve as examples of this type of humor. A situational or universal type of humor without much loss can be transferred to a different linguistic environment.

The second type of humor includes jokes that are based on the cultural base of the source language. This type of humor is harder to translate because of the lack of similar background in the translation language, and it provides some knowledge of the original cultural environment. That is why it is less likely to cause an adequate response in the "culturally unprepared" audience - because it is often unclear about the form of humor, - and sometimes it is not perceived as a humor. The examples of the second type of humor can be jokes about national minorities in different countries, jokes based on specific realities, and jokes, the basis of which is the usage of professionalisms and jargon, as well as satire.

The third and last group of humor classification is represented by linguistic humor. This type of humor in its structure is the most difficult to decode into a different language, because it is based on a game of words (pun), which, unfortunately, is usually considered to be not subject to translation.

In linguistics comic is regarded as a special type of creativity, associated with both verbal and non-verbal communication. Thus, the two forms of comic, namely, the linguistic and non-linguistic, are singled out already at the first attempts of comprehension of its nature. Taking as a basis the nature of the comic in the original, that is, what is intended by the author containing humorous potential, all jokes are divided into situational and linguistic. In situational jokes the nature of the comic stems out from the situation itself, the addressee understands the humor not because of the interpretation language characters, but because of the direct perception of the situation (a classic example of such jokes is the humor of Charlie Chaplin).

The language elements of the comic are purely elements of the situation that function as well as the actions of heroes or dynamic changes. These language elements do not create the nature of the conflict, which is based on the joke, they simply inform the recipient of some information necessary to create a comic potential, purely pointing to a certain aspect of the situation, without providing estimates or interpretations. It seems possible to name such function of verbal signs in jokes indicative [7, p. 57].

In language jokes the nature of the comic is generated precisely in the verbal plane, with the sit- uation being purely a backdrop for the joke or its context. Language jokes are built solely on replicas of heroes, which at the same time cannot perform any active action, and the circumstances of the interaction will remain unchanged [5, p. 55]. Linguistic comism has an illocutive force that is subordinate to the general communication strategy of the utterance [4, p. 225].

According to A. V. Karasyk, the linguistic characteristics of the comic are determined "as specific duplicates, exaggeration and simplification, as well as violations between the subject, conceptual and actual symbolic characteristics of the statement. Each proposed model of humorous text is constructed as a typology of content disorders: semantic, pragmatic, syntical and formal-iconic" [1, p. 28]. V. S. Sannikov divides jokes into two types: subject and language. For subject matter jokes the comism of the situation is important, and for language-applied linguistic mechanism [6, p. 56], situational comism is created in the context of the work, that is, thanks to the situation described by the author. Linguistic comism, in its turn, is created by different language means. The tools used by the author can be isolated in the process of analyzing the text of works. Techniques of comic are generated by various means and they are formed primarily by language means.

The main tricks of the comic are allegory, deformation, unexpected, inconsistency, misunderstanding and reception exposing through anachronisms. In the language prose a special role in creating a comic effect belongs to the lexical means. As endorsement and damnation, the lexical allegory has ancient history and origin associated with comparisons. As for the comical nature of the tropes, such as metaphors, metonymy, epithets, oxymoron and comparisons, they laid great ease with which they turn into comic means, which opens up wide opportunities in front of satire. The intensity of their use is related to individual writer style. Phraseological units serve as for a comic expression in the following three cases: a) accompanied by ironic intonation; b) historically formed in a language in comic quality; c) provide a successful combination with other words and expressions [3, p. 49].

Thus, scientists emphasize the multilevel language and linguistic stylistic tools, due to which the writers create bright humorous, ironic or satirical effects. There are a lot of approaches to classification of tropes. Considering the tropes in the context of stylistics V. A. Kukharenko shares the trops (stylistic tools) on lexical (metaphor, metonymy, synecdoche, pun, irony, epithets, hyperbole, oxymoron), syntacti- 
cal (rhetorical question etc.) and lexical-syntactical (antithesis, climax, anticlimax, simile, litotes, periphrasis) [2, p. 36].

O. M. Morokhovskyy studies trops in the context of semasiology. The scientist divides trops into expressive means (replacement figures) and stylistic devices. Substitution figures are means of the secondary nomination that occur on the basis of similarity of two objects established to be more or less subjective, or adjacent. Thus, the substitution figures are the totality of the secondary names that exist in the language or in the "finished" form, or are formed in the broadcasting on the basis of regular models.

According to the systematic methods of comic, the methods of comic function on the levels of plot, character and the language level. The first, in its turn, include techniques at the level of the story, situation or text, as well as the author's stamp, the latter at the character level - are built on the characteristics of heroes, in particular on the description of appearance, thoughts and situational statements, the third ones - contain stylistic, lexical, phonetic and complex means of making comic, in particular a language game. It should be noted that in many cases there is a mixing of various techniques and means to achieve the highest degree of comity.

Humorous flavor is created by a lot of linguistic means. The most expressive include the following: contrasting-comic comparisons or juxtaposition of certain facts, signs; the discrepancy of the conclusion; exaggeration of real qualities of people, animals, and objects; the usage of words in the meaning that does not correspond to a particular situation, etc.

If we talk about humor, and the specifics of its translation it lies not only in preserving original pragmatic purpose, but also in the adequacy of the reproduction of the national character of the comic means of another language. Translation difficulties are not only related to the knowledge of the language, but we mean the ability to find interlingual pragmatic equivalents in different language systems. Inaccurate transfer of the comic leads to communication failures and the integrity of text perception.

The following methods are highlighted to reproduce the category of comic in translating: finding a situational equivalent; finding an equivalent with an increased level of emotionality; transcoding; combination of transcription and transliteration with the addition of word-forming morpheme; lexical and semantic transformations; phonetically-immitating transformations [4, p. 204]. Among the means of creating comic and means of their translation we single out, first of all, the formation of comic on phra- seological level; the usage of individually-authorial metaphors; and introduction of extraordinary comparisons. In the transfer of means to create comic a translator has to customize ways to solve a translation problem to achieve a comic effect.

Comic becomes an invariant of translation, if it belongs to the dominant style of the author. Considering a special case of creating comic the translator has to define, what means allow to cause a comic effect in the original language. And then it is determined whether he can achieve the same means of the comic effect in translation or not. If it is impossible to preserve the content and the form simultaneously with the pragmatic effect the translator is shifted with losses.

When minimizing translation losses and appropriate comic transfer translators must have a high degree of translation competence and be able to prioritize, choosing between components of the artwork. The translation process gradually refers to the pre-translation analysis, during which the translator meets with the author's work to identify the main features of the individual author's style. Purely translation analysis involves the determination of translation invariants, subordinate key function of the work, as well as the search of strategies and tactics of translation. Translators have to evaluate translation options at minimal syntactically-completed units, such as sentences. While preserving the harmony between all the levels and displaying most of the invariants the translation can be considered adequate.

The complexity of reproduction of comic in general and irony in particular is caused by the fact that the proto-texts used to create irony, in source language culture mostly do not belong to precedent texts. Despite the presence of translations of these texts, and aspect that the cited fragments of these works in translations have not become known expressions, they do not have clear connotations and are not associated directly with their primary contexts, that is, cannot function in the target text as signs. Thus, to reproduce the translation of irony, it is necessary to compensate for insufficient semiotic allusions.

Conclusions. The category of comic as a component of non-verbal communication and as one of the means of perception of the world has always been of great significance and had linguistic and informative value. Under the comic effect, we understand the impact and pragmatics of jokes, based on inconsistencies in the values, for example, literal and contextual, causing laughter. Traditionally, the means of creating comic effect is taken to include stylistic devices and expressive means such as irony, 
sarcasm, pun, allusion, periphrases, oxymoron, metaphor and metonymy.

The basic concept on the classification of the comic is revealed. Scholars allocate from two (humor and satire) to seven (humor, satire, joke, ridicule, irony, grotesque, sarcasm) main forms of comic, while in some concepts the humor and satire are regarded as two equal basic forms of comic, and the rest (irony, grotesque, etc.) have the status of expressive means of comic, which are used by humor and satire. In linguistics humor is divided into three main groups: universal, based on the component of the original culture (culture-based), and linguistic.

The linguistic stylistic parameters of the comic are studied. In language the nature of comic is generated precisely in the verbal plane, with the situation being purely a backdrop for the joke, being its context. Linguistic category of comic has an illocutive force that is subordinate to the general communication strategy of the statement.

As for the translation of comic, we found out that translators face certain difficulties. To overcome them it is recommended to find a situational equivalent; to find an equivalent with an increased level of emotionality; to use transcoding; to use the combination of transcription and transliteration with the addition of word-forming morpheme; to apply lexical and semantic and phonetically-imitating transformations.

\section{References:}

1. Карасик В. И. Языковой круг: личность, концепты, дискурс. Москва : Языки славянской культуры, 2004. $560 \mathrm{c}$

2. Кухаренко В. А. Практикум по стилистике английского языка. Москва : Высшая школа, 1996. 144 с.

3. Петрова О. Г. Ирония и разные типы комического в художественном тексте. Rozwoj Nauk Humanistycznycn : materialy miedzunar. nauk.-prak. conf. 2012. URL: http://конференция.com.ua/pages/ view/349.

4. Райс К. Классификация текстов и методы перевода. Вопросы теории перевода в зарубежной лингвистике. Москва, 1978. С. 202-228.

5. Рецкер Я. И. Теория перевода и переводческая практика. Очерки лингвистической теории перевода. Москва : Р. Валент, 2004. 240 с.

6. Санников В. З. Каламбур как семантический феномен. Вопросы языкознания. 1995. № 3. С. 56-70.

7. Скребнев Ю. М. Основы стилистики английского языка. Москва : Астрель, 2003. 221 с.

8. Уткина А. В. Когнитивные модели комического и их репрезентации в русском и английском языках: сравнительно-сопоставительный анализ : дисс. ... канд. филол. наук. Пятигорск, 2006. 207 с.

\section{АГС६Ва В. О. КОМІЧНЕ ЯК ЛІНГВІСТИЧНА КАТЕГОРІЯ: КЛАСИФІКАЦІЯ, ПАРАМЕТРИ ТА ПЕРЕКЛАД}

У статті аналізується поняття комічного як лінгвістичної категорії. Акцентується увага на таких аспектах категорії комічного, як класифікація, параметри комічного та труднощі перекладу.

Виявлено, щуо поняття концепиії комічного виходить за межі лінгвістичного аспекту. Саме тому ие мовне явище також вивчається з погляду соиіокультурного аспекту та норм поведінки людини в суспільстві. Категорія комічного складна й неоднозначна. Загалом у межах иього поняття ми розумісмо вплив жартів (наприклад, тих, що викликають сміх). Виокремлюють декілька методів, які допомагають досягти комічного. Серед них розрізняють іронію, сарказм, каламбур, алюзію, перифразу, оксюморон, метафору тощо. Через багатоаспектний характер комічного ией термін часто використовується одночасно з його схожими синонімами, такими як гумор, сміх, смішний, безглуздий, дотепний, жарт, іронія, сарказм, сатира тощо. Щодо категорій комічного вчені виділяють такі: аналіз стилю комічного, виділення й опис особливостей комічного тексту стилю конкретних авторів; визначення та вивчення мови й методів реалізачії категорії комічного на прикладі конкретної мови; характеристику мовних параметрів конкретних підвидів категорії комічного.

Категорія комічного також розділяється на три групи. Перша група представлена зрозумілим і легко впізнаваним гумором на основі комічної ситуаиії. Другий тип представлено жартами на основі культурної бази вихідної мови. А до третього типу ми відносимо мовний гумор. Цей вид гумору у своїй структурі є найскладнішим для декодування іншою мовою, оскільки засновується на грі слів (каламбурі), що, на жаль, зазвичай не підлягає перекладу. Щодо аспекту перекладу необхідно звертатися до використання ситуаиійного еквіваленту, еквіваленту з підвищеним рівнем емоційності, а також використовувати перекодування чи комбінаџію транскрипиї та транслітерації з додаванням словоутворюючих морфем або застосовувати лексико-семантичні та фонетично-імітаційні трансформації.

Ключові слова: мовна категорія, комічне, переклад, класифікачія комічного, параметри комічного. 